\title{
Substitutional Studies of Powdered Palm Kernel Shell (PPKS) for Carbon Black, Kaolin and Calcium Carbonate as Fillers in Natural Rubber Compounding
}

\section{ISSN: 2576-8840}

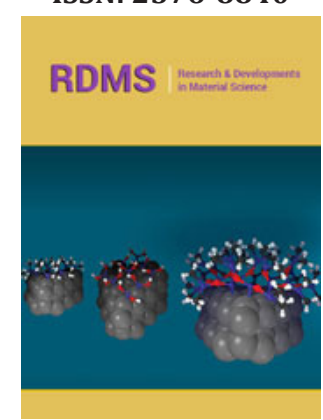

*Corresponding author: Awatefe KJ, Chemical Sciences Department, Edwin Clark University, Nigeria

Submission: 侮 May 18, 2020

Published: 㱕 May 27, 2020

Volume 13 - Issue 4

How to cite this article: Awatefe $\mathrm{KJ}$, Idibie CA, Olagbemiro TO, Akaranta 0 . Substitutional Studies of Powdered Palm Kernel Shell (PPKS) for Carbon Black, Kaolin and Calcium Carbonate as Fillers in Natural Rubber Compounding. Res Dev Material Sci. 13(4). RDMS.000816. 2020. DOI: 10.31031/RDMS.2020.13.000816

Copyright@ Awatefe KJ, This article is distributed under the terms of the Creative Commons Attribution 4.0 International License, which permits unrestricted use and redistribution provided that the original author and source are credited.

\section{Awatefe $\mathrm{KJ}^{1 *}$, Idibie $\mathrm{CA}^{1}$, Olagbemiro $\mathrm{TO}^{1}$ and Akaranta $\mathrm{O}^{2}$}

${ }^{1}$ Chemical Sciences Department, Edwin Clark University, Nigeria

${ }^{2}$ Pure and Industrial Chemistry Department, University of Port-Harcourt, Nigeria

\begin{abstract}
The possibility of Substituting Powdered Palm Kernel Shell (PPKS) for conventional fillers such as carbon black (CBN330), Kaolin (KA) and Calcium Carbonate $\left(\mathrm{CaCO}_{3}\right)$ in natural rubber compounding was investigated. 37 samples of natural rubber mixes were compounded, using 0-60pphr loading levels of the fillers. A zero-filler compounded sample was used as control. The rheological and cure properties of the cured samples and the physico-chemical properties of the filler samples were tested using the appropriate test equipment and ASTM methods of analysis. The physico-mechanical properties of the filled vulcanizates were also determined using the appropriate test machines. The \% equilibrium swelling properties of the vulcanizates were also compared. The results obtained reveal that PPKS exhibited improved compounding and cure characteristics than $\mathrm{CBN330}$, Kaolin and $\mathrm{CaCO}_{3}$, and also has better hardness, but less tensile strength than CBN330. PPKS had better tensile strength, modulus at $100 \%$ elongation, elongation at break (EB), abrasion resistance and hardness than Kaolin and $\mathrm{CaCO}_{3}$ filled vulcanizates. However PPKS showed less \% of equilibrium swelling than CBN330, Kaolin and CaCO3. Conclusively, PPKS can be used as semi-reinforcing filler and a substitute for CBN330 where EB and hardness are desired. Therefore PPKS can be completely substituted for Kaolin and $\mathrm{CaCO}_{3}$ in Natural rubber vulcanized products.
\end{abstract}

Keywords: Substitution; Fillers; Powdered palm kernel shell; Carbon black; Physico-chemical; Physicochanical

\section{Introduction}

Natural rubber crumbs have always been the major input in rubber compounding, while reinforcing fillers such as carbon black, $\left(\mathrm{CaCO}_{3}\right)$ and Kaolin are the conventional nonrenewable fillers used. Suitable replaceable fillers that are environmentally friendly, nonhealth hazard causing, and do not cause environmental pollution, that can replace the nonrenewable conventional filler, such as CBN330 are constantly being researched and sourced for [1]. The utilization of cocoa-pod husks and rubber seed shells as fillers in natural rubber compounding have been studied [2]. Equally, the mechanical properties of natural rubber reinforced by agricultural waste products have been evaluated [3]. Rice husks have been discovered as potential filler in epoxidized natural rubber [4]. Calcium Carbonate $\left(\mathrm{CaCO}_{3}\right)$ has been studied as filler with flame retardant properties in Styrene-butadiene rubber [5]. Carbonized plantain peel has been investigated to substitute N330 Carbon black, to improve the cure characteristics, physico-mechanical and equilibrium swelling properties in natural rubber vulcanizates [6]. Rheological rubber compounded with blend of carbonized melon seed shell and carbon black has also been investigated [7]. Tensile strength properties of oil palm empty fruit Bunch-Polyurethane composite have been Studied [8].

From all of the above findings, there has not been any suitable replacement or substitution for carbon black, especially in the area of improved tensile strength in natural rubber 
compounding applications. This has prompted the investigation of PPKS, a low cost agricultural waste renewable material that is environmentally friendly, as suitable filler for replacement of conventional filler (like $\mathrm{CBN} 330$, Kaolin and $\mathrm{CaCO}_{3}$ ) in natural rubber compounding.

\section{Materials and Methods}

\section{Materials}

Materials used and their sources are as follows: Natural rubber crumb (NSR-10) was obtained from Omatseye Rubber Factory, Sapele, Delta State; Stearic acid; Zinc Oxide; processing oil (Flectol), Sulphur, TMTD, were obtained from British Drug House, Poole, England; Carbon Black (N330), was obtained from NNPC Carbon Black Plant, Ekpan-Warri, Delta State, Nigeria; Calcium Carbonate and Kaolin were obtained from Salami Orogho Quarry Company,
Okpilla, Edo State, Nigeria; Palm Kernel Shell, obtaind from Palm Estate, Mosogar, Sapele, Delta State, Nigeria.

\section{Methods}

Material preparations: The Palm Kernel shell (PKS) were ground into fine particle sizes of 60,106 and 230um respectively, using a piston and mortar and a screen sieve of appropriate particle sizes. They were stored for further use. Kaolin and $\mathrm{CaCO}_{3}$ were also screened to the same particle size as the PKS. The N330 Carbon Black was used as obtained from NNPC, Warri and Delta State.

Preparation of the natural rubber mixes (compounding): The formulation of 37 mixes in gms were prepared, varying the loadings of the fillers and particle sizes, while the zero filler loading was used as a control sample as shown in Table 1 . The best fillers of $30 \mathrm{~g}$ loading samples mixes were used for further test analysis.

Table 1: Natural rubber/filler formulation mixes.

\begin{tabular}{|c|c|c|c|c|c|}
\hline \multirow{2}{*}{ Material } & \multicolumn{5}{|c|}{ Filler } \\
\hline & Zero filler & CBN330 & PPKS & $\mathrm{CaCO}_{3}$ & PPKS \\
\hline N Rubber & 100 & 100 & 100 & 100 & 100 \\
\hline Stearic acid & 2 & 2 & 2 & 2 & 2 \\
\hline Zinc oxide & 6 & 6 & 6 & 6 & 6 \\
\hline Electo H (TMQ) & 2 & 2 & 2 & 2 & 2 \\
\hline MBT & 1 & 1 & 1 & 1 & 1 \\
\hline Processing oil (Flextol) & 10 & 10 & 10 & 10 & 10 \\
\hline Sulphur & 2 & 2 & 2 & 2 & 2 \\
\hline Carbon black & - & 30 & - & - & - \\
\hline Kaolin & - & - & - & - & 30 \\
\hline $\mathrm{CaCO}_{3}$ & - & - & - & 30 & - \\
\hline PPKS & - & - & 30 & - & - \\
\hline Mixing time (mins) & 10 & 17 & 18 & 19 & 22 \\
\hline
\end{tabular}

\section{Experimental Test Procedure}

The physico-chemical analysis of the various fillers in terms of the Percentage Ash and moisture content, iodine adsorption number, bulk density, $\mathrm{PH}$ value were done using the conventional methods (ASTM) [9].

The cure characteristics, that is thee rheological (flow) properties analysis were done using the oscillating disc rheometer. The physico-mechanical analysis which include Hardness, Abrasion resistance, Tensile Strength, 100\% Elongation, and Percentage equilibrium swelling tests were done, using the appropriate test machines and standard procedure of ASTM [10].

\section{Resullts and Discussions}

The physico-chemical properties of the fillers for different materials are shown in Table 2, while the cure characteristics result is shown in Table 3. From the result as shown in Table 2, PPKS has higher acidity, moisture content and bulk density, but less loss on ignition and iodine adsorption number than CB (N330). The rheological properties of PPKS filled vulcanizate improved over CB
(N330) which accommodated the strain of the polymer mix with the size and loading of the filler [11].

Table 2: Physico-chemical properties of the fillers.

\begin{tabular}{|c|c|c|c|c|}
\hline \multirow{2}{*}{ Parameter } & \multicolumn{4}{|c|}{ Filler } \\
\cline { 2 - 5 } & PPKS & CB (N330) & Kaolin & $\mathbf{C a C O}_{3}$ \\
\hline $\begin{array}{c}\text { Loss of } \\
\text { ignition at } \\
\left(350^{\circ} \mathrm{C}\right)\end{array}$ & 65.58 & 71.0 & 59.0 & 53.0 \\
\hline $\begin{array}{c}\text { Moisture } \\
\text { content at } \\
\left(1,280^{\circ} \mathrm{C}\right)\end{array}$ & 13.6 & 5.32 & 8.15 & 18.54 \\
\hline Ph Value & 6.80 & 6.50 & 8.60 & 8.50 \\
\hline $\begin{array}{c}\text { Iodine } \\
\text { adsorption } \\
\text { No. (ml/g) }\end{array}$ & 4.40 & 4.71 & 4.07 & 4.30 \\
\hline $\begin{array}{c}\text { Mesh size } \\
(\text { um) }\end{array}$ & 60.0 & 35.0 & 60.0 & 60.0 \\
\hline $\begin{array}{c}\text { Bulk density } \\
\text { (gm/v) }\end{array}$ & 0.54 & 0.30 & 0.75 & 0.90 \\
\hline
\end{tabular}


Table 3: Rheological (cure) properties.

\begin{tabular}{|c|c|c|c|c|c|c|c|c|}
\hline \multirow{2}{*}{ Filler Loading (pphr) } & \multicolumn{9}{|c|}{ Scorch Time (mins) } & \multicolumn{4}{c|}{ Cure Time (mins) } \\
\cline { 2 - 10 } & PPKS & CB N330 & Kaolin & CaCO $_{3}$ & PPKS & CB N330 $^{\text {Kaolin }}$ & CaCO $_{3}$ \\
\hline 0 & 2.50 & 2.40 & 4.11 & 4.20 & 5.14 & 5.48 & 6.19 & 6.20 \\
\hline 10 & 2.07 & 2.37 & 3.30 & 2.35 & 5.01 & 6.13 & 6.46 & 4.58 \\
\hline 20 & 2.17 & 3.09 & 3.29 & 3.14 & 5.32 & 6.28 & 8.05 & 5.50 \\
\hline 30 & 2.10 & 2.44 & 4.30 & 3.01 & 4.32 & 6.05 & 10.18 & 5.40 \\
\hline 40 & 2.34 & 2.41 & 5.59 & 2.58 & 5.07 & 5.46 & 10.54 & 5.40 \\
\hline 50 & 2.42 & 2.42 & 5.48 & 2.31 & 5.48 & 5.50 & 10.69 & 5.08 \\
\hline 60 & 2.55 & 2.11 & 3.53 & 2.52 & 6.08 & 5.50 & 10.75 & 5.36 \\
\hline
\end{tabular}

Better rheological properties were also obtained for PPKS filled vulcanizates over $\mathrm{CaCO}_{3}$ and Kaolin, as shown in Table 3. The physico-mechanical properties of PPKS filled vulcanizates were compared against CB (N330), $\mathrm{CaCO}_{3}$ and Kaolin as shown in Table 4.
The results obtained show comparable tensile strength of PPKS and CB (N330) fillers, while PPKS fillers exhibited better modulus at $100 \%$ elongation, EB, hardness, abrasion resistance and percentage equilibrium swelling properties over $\mathrm{CB}$ (N330), $\mathrm{CaCO}_{3}$ and Kaolin.

Table 4: Physico-mechanical properties.

\begin{tabular}{|c|c|c|c|c|c|}
\hline \multirow{2}{*}{ Parameter } & \multicolumn{5}{|c|}{ Filler } \\
\hline & Zero filler & PPKS & CB(N330) & Kaolin & $\mathrm{CaCO}_{3}$ \\
\hline Tensile strength (Mpa) & 17 & 24 & 27 & 22 & 21 \\
\hline 100\% Elongation & 10 & 11 & 13 & 11 & 10 \\
\hline Elongation at break (\%) & 285 & 330 & 285 & 315 & 260 \\
\hline Hardness (IRHD) & 39 & 54 & 47 & 36 & 36 \\
\hline Abrasion resistance $(\mathrm{mg} / 1000)$ & 0.54 & 0.18 & 0.17 & 0.89 & 0.14 \\
\hline
\end{tabular}

Improved tensile strength was observed in PPKS filler over $\mathrm{CaCO}_{3}$ and Kaolin. The results obtained may be explained that fillers with higher carbon content, provide greater reinforcement than those with lower carbon content, because carbon itself is a good reinforcing filler [11], which is exhibited in better reinforcing ability of CB (N330) over PPKS filler.

The tensile modulus and hardness are controlled by the surface activity and polymer mix-filler interaction as reported by [11]. These properties have been exhibited by the PPKS vulcanized filler over $\mathrm{CB}$ (N330), $\mathrm{CaCO}_{3}$ and Kaolin as can be observed in the results obtained in Table 4.

Table 5: \% equilibrium swelling properties.

\begin{tabular}{|c|c|c|c|}
\hline \multirow{2}{*}{$\begin{array}{c}\text { Filled } \\
\text { Vulcanizate }\end{array}$} & \multicolumn{3}{|c|}{ Solvent } \\
\cline { 2 - 4 } & Kerosene & Benzene & Diesel \\
\hline Zero filler & 40 & 95 & 40 \\
\hline CN(N330) & 35 & 48 & 36 \\
\hline Kaolin (KA) & 60 & 78 & 45 \\
\hline CaCO3 & 40 & 85 & 40 \\
\hline PPKS & 30 & 45 & 30 \\
\hline
\end{tabular}

The results of the low \% equilibrium swelling in PPKS filled NR vulcanizate as shown in Table 5 , which is consistent with earlier studies [12], that low equilibrium swelling may be due to filler related parameters, such as particle size, acidity and moisture content, which are critical factors for forming interfacial bond with NR Matrix. These properties were exhibited by PPKS filled vulcanizates, hence the improved performance over CB (N330), Kaolin and $\mathrm{CaCO}_{3}$ fillers vulcanizates, were observed. The least $\%$ equilibrium were obtained in Kerosene and highest in benzene due to the smaller size benzene molecules having higher diffusion rate than individual molecule of kerosene and diesel which are mixtures of alkane hydrocarbon [13,14].

\section{Conclusion}

In conclusion, PPKS filler has been found to be semi-reinforcing filler with slightly less tensile properties than CB (N330). Subsequently, PPKS filler can be substituted for CB (N330) where the performance properties such as elongation at break, hardness and abrasion resistance are desired. PPKS filler also exhibited better \% equilibrium swelling properties over CB (N330), Kaolin and $\mathrm{CaCO}_{3}$ and can be used as good swelling resistance vulcanized NR product of benzene, kerosene and diesel solvents. Finally, PPKS filler can be conveniently used as a substitute for Kaolin and $\mathrm{CaCO}_{3}$ fillers in NR compounding to produce relevant rubber moldable products.

\section{References}

1. Asore EJ (2000) An introduction to rubber technology. Josey Books Ltd., Benin-City, Nigeria, pp. 1-141.

2. Imanah JE (2003) Studies in the utilization of cocoa-pod husk and rubber seed shell as filler in natural rubber compounding. Ph.D Thesis, University of Benin, Benin-City, Nigeria, pp. 95-200.

3. Okieimen FE, Imanah JE (2003) Characterization of agricultural waste products as fillers in natural rubber formulations. Nig J of Polymer Technology 3(1): 201-207. 
4. Ishiaku US, Hashim AS, Azahari A (1997) An investigation of the potentia of rice husk as filler for expoxidized natural rubber-fatique behavior. European Polymer Journal 33(10): 73-81.

5. Mishra S, Shimpi NG (2005) Mechanical properties of flame-retardant properties of styrene-butadiene rubber filled with $\mathrm{CaCO}_{3}$ as a filler and linseed oil as an extender. Journal of Applied Polymer Science 98(6): 563-571.

6. Sogbaike DE, Okieimen FE, and Edojariogba P (2005) Effect of substitution of N330 carbon black with carbonized plantain peels on the cure characteristics, physico-mechanical and swelling properties of natural rubber vulcanizates. Chemical Journal 1: 24-29.

7. Iyasele JU, Okieimen FE (2008) Cure characteristics and rheological properties of melon seed shell-filled natural rubber. Proceedings of the $27^{\text {th }}$ International Conference of the Chemical Society of Nigeria, BeninCity, Nigeria, pp. 272-277.

8. Rozman HD, Tay GS, Abubaka A, Kumar RN (2001) Tensile properties of oil palm empty fruit branch-polyur-ethane composites. European Polymer Journal 37: 1759-1769.

9. ASTM D3184 (1983) Standard methods for rubber compounding. American Society for Testing and Materials, West Conshohochen PA, USA, pp. 100-110.
10. ASTM D412 (1983) Standard method for testing tensile properties of rubber. pp. 200-220.

11. Ahmad AMDH, Abdullah I (2004) Mechanical properties of filled NR/ LLDPE blends. Iranian Polymer Journal 13(3): 173-178.

12. Sogbaike DE, Okieimen FE, Edojariogba P (2005) Effect of substitution of N330 carbon black with carbonized plantain peels on the cure characteristics, physico-mechanical and swelling properties of natural rubber vulcanizates. Chemical Journal 1: 24-29.

13. Akinlabi AK, Okieimen FE (2004) Solvent resistance and thermal aging of blends of natural rubber and expoxidized low molecular weight of natural rubber, Proceedings of the $27^{\text {th }}$ International Conference of Chemical Society of Nigeria, Benin-City, Nigeria, pp. 293-300.

14. Sogbaike DE, Okieimen FE, Edojariogba P (2005) Effect of substitution of N330 carbon black with carbonized plantain peels on the cure characteristics physico-mechanical and swelling properties of natural rubber vulcanizates. Chemical Journal 1: 24-29. 